\title{
ASIAN-AFRICAN LEGAL CONSULTATIVE COMMITTEE ANNUAL SURVEY OF ACTIVITIES 1992-1993, INCLUDING THE WORK OF ITS THIRTY-SECOND SESSION HELD IN KAMPALA, 1-6 FEBRUARY 1993*
}

\section{Membership and Organization}

2. Questions under Consideration by the International Law Commission

2.1 Draft Code of Crimes against the Peace and Security of Mankind: the Establishment of an International Criminal Court

2.2 State responsibility

2.3 International Liability for Injurious Consequences Arising Out of Acts Not Prohibited by International Law

2.4 Other matters

Decision

3. Legal Problems Referred to the Committee by Participating States

3.1 Status and Treatment of Refugees

3.2 Law of International Rivers

3.3 Law of the Sea

3.4 Deportation of Palestinians

3.5 Responsibility and Accountability of Former Colonial Powers

4. Matters of common concern having legal implications

4.1 The UN Conference on Environment and Development

4.2 UN Decade of International Law

4.3 Debt Burden of Developing Countries

4.4 Preparation for the World Conference on Human Rights

4.5 Trade Law Matters

* Edited by M.C.W. Pinto, General Editor The account of the main activities of the Committee, and the main views expressed during or in connections with the Committee's thirty-first session, has been adapted from the Secretariat's Report of the Thirty-Second Report (Report)

Asian Yearbook of International Law, Volume 3 (Ko Swan Sik et al., eds.; 0-7923-2708-X; (C) 1994 Kluwer Academic Publishers; printed in Great Britain), pp. 259-301 


\section{MEMBERSHIP AND ORGANIZATION}

1. Myanmar having been re-admitted to membership, there were forty-three Members of the Committee on 1 February 1993: Egypt, Bangladesh, China, Cyprus, Gambia, Ghana, India, Indonesia, Iran, Iraq, Japan, Jordan, Kenya, Democratic People's Republic of Korea, Republic of Korea, Kuwait, Libya, Malaysia, Mauritius, Mongolia, Myanmar, Nepal, Nigeria, Oman, Pakistan, Palestine, Philippines, Qatar, Saudi Arabia, Senegal, Sierra Leone, Singapore, Somalia, Sri Lanka, Sudan, Syria, Tanzania, Thailand, Turkey, Uganda, United Arab Emirates, and Yemen Arab Republic. Botswana is an Associate Member. The account of the main activities of the Committee, and the main views expressed during or in connection with the Committee's Thirty-second Session has been adapted from the Secretariat's Report of the Thirty-second Session ("Report").

2. The Thirty-second Session of the Committee was held at Kampala from 16 February 1993 at the invitation of the Government of Uganda. His Excellency YowERI KAGUTA MUSEVENI President of the Republic of Uganda, delivered the inaugural address. Mr. A.B. MAYANJA, Third Deputy Prime Minister, Minister of Justice and Attorney General of Uganda was elected President and Mr. MIRZA GulAM HAFIZ, Minister for Law, Justice and Parliamentary Affairs of Bangladesh was elected Vice-President. Mr. MIRZA ASADUZZAMAN AL-FAROUQI (Bangladesh) was elected Chairman of the SubCommittee on International Trade Law Matters, and Mr. DONALD NYAKAIRU (Uganda) was elected Rapporteur of the Sub-Committee. The open-ended Working Group on Human Rights (with a core membership of Egypt, China, India, Japan, Iran, Kenya, Tanzania and Uganda) elected Mr. L.T. TIBARUHA (Uganda) as its Chairman. The Secretary-General of the Committee, Mr. FRANK X. NJENGA, and members of the AALCC Secretariat were responsible for the organization of the session.

3. The Committee decided to accept the invitation of the Government of Japan to hold its Thirty-third Session in Tokyo. In response to an offer by the Government of Qatar to act as host to the Committee, and a proposal that the Committee's Headquarters be moved from New Delhi to Doha, the Committee, after due deliberation (Report, pp. 140-7) adopted the following resolution (Report, pp. 216-7):

RESOLUTION ON THE PROPOSED RELOCATION OF THE HEADQUARTERS OF AALCC FROM INDIA TO QATAR ADOPTED AT THE SIXTH PLENARY MEETING HELD ON 4 FEBRUARY, 1993.

THE ASIAN-AFRICAN LEGAL CONSULTATIVE COMMITTEE 
Recalling its resolution dated 1 February 1992 adopted at the Thirty First session in Islamabad, Pakistan regarding Headquarters Agreement;

Having considered a report by the Secretary-General contained in Document No.AALCC $|X X X I I|$ Kampala $|93| 20$;

Noting the historic role of the Government of India as one of the founders of the Non-Aligned Movement;

Noting with appreciation the contribution of the Government of India to the spirit and aspirations of the Non-Aligned Movement by hosting AALCC since its foundation;

Noting with satisfaction that the unfailing back-up of the Indian Government to the AALCC's activities has helped it to flourish and expand on both regional and international levels, and thus to contribute in sharing international law developments and its codification;

Noting with great satisfaction the Indian representative's assurance that the Indian Government will continue its full-fledged commitment to the AALCC's principles, purposes and activities;

Decides:

(1) To express its deep appreciation and esteem to the Government of India for the tremendous efforts and sincere support rendered to the AALCC for more than three decades during which the AALCC was based in New Delhi.

(2) To express its thanks to the Government of the State of Qatar for its generous offer to host the Headquarters of the AALCC in Doha which it accepts, unless the Indian Government would make a better offer in one month after the conclusion of the ThirtySecond Session of the AALCC, in which case the President would hold an Intersessional Meeting at Ambassadorial level in New Delhi.

(3) To request the Secretary-General of the AALCC and the President of the ThirtySecond Session to hold consultations with the Government of Qatar to consider and finalize the relevant details as soon as possible.

(4) To request the Secretary-General to report on this matter, at the earliest possible convenience, to the Liaison Officers in New Delhi.

(5) To request the Secretary-General to report also on the financial implications involved in the moving of the Headquarters and the necessary staff from New Delhi to Doha; and

(6) To report on the progress in the implementation of this decision to the Thirty-Third Session of the AALCC.

\section{QUESTIONS UNDER CONSIDERATION BY THE INTER- NATIONAL LAW COMMISSION (Report, pp. 104, 134-9, 223-4)}

4. The Committee had before it a Secretariat document entitled Report on the Work of the International Law Commission at its Forty-fourth Session (Doc. No. AALCC/XXXII/KAMPALA/93/1) containing surveys of the Commission's work on three topics, viz. Draft Code of Crimes against the Peace and Security of Mankind: the establishment of an International Criminal Court; International liability for injurious consequences arising out of acts not prohibited by international law; and State responsibility. On another topic 
dealt with by the Commission, viz. Non-navigational uses of international watercourses, the Committee had before it a Secretariat document entitled The Law of International Rivers: a Preliminary Study relating to River System Agreements (Doc. No. AALCC/XXXII/KAMPALA/93/6) prepared for use in connection with the Committee's consideration of a separate item 'International Rivers' (reported on below, paragraphs 26-28) and containing references to the work of the International Law Commission on international watercourses.

\subsection{Draft Code of Crimes against the Peace and Security of Mankind: the establishment of an International Criminal Court}

5. The delegate of China said that the establishment of an International Criminal Court would strengthen international cooperation to curb and combat international and transnational crime, and would forestall international disputes that could arise due to the existence of a diversity of national criminal jurisdictions. Noting, that there were several issues concerning establishment of such a court, including the need to uphold the principles of the Charter of the United Nations, he urged the Commission to study all aspects of the subject before drafting the statute of the proposed court. The delegate of Japan said that he favoured the General Assembly's mandate to the Commission to draft the statute of the proposed court, and urged that the Commission ensure that the procedure followed by the court would be characterized by due process, independence and impartiality. The delegate of Tanzania said that the issue of the establishment of an international criminal court required consideration of some basic principles of criminal justice, such as violation of a specific law, maintenance of peace and preservation of law and order, the rules relating to procedure and evidence, the right to defence and, very importantly, questions relating to original and appellate jurisdictions.

6. The delegate of Kenya said that questions relating to such matters as the jurisdiction and competence of the proposed court could be resolved only after certain political considerations had been addressed, among them the universal acceptance and applicability of the jurisdiction of the court. The delegate of the Democratic People's Republic of Korea said that any mechanism established to deal with criminal acts should have a universal character.

7. The delegate of Cyprus said that the proposed Draft Code should clearly define crimes such as aggression, ethnic cleansing, demographic alteration, and illegal transfer of populations. If the proposed international criminal court were to be vested with compulsory jurisdiction, it would, in this view, reflect the will of the community that there should be uniform application of international law.

8. The delegate of the Libyan Arab Jamahiriya expressed reservations regarding 
the proposal to establish an international criminal court.

\subsection{State responsibility}

9. On the subject of 'counter measures', which had been considered by the Commission in some detail, the delegate of Japan expressed the view that countermeasures would remain an effective instrument in dealing with internationally wrongful acts in the absence of an enforcement mechanism under international law. In his opinion, it would be appropriate to regulate such countermeasures, rather than shy away from considering them. The extent to which countermeasures might be allowed to be resorted to, would be related to the dispute settlement regime. He expressed the hope that the Commission would expedite the drafting process on this topic.

10. The delegate of China said that in as much as countermeasures could be used as a tool of power politics, that aspect of the subject needed further consideration.

11. The delegate of India said that the Commission in its work on the topic should focus on the role of peaceful settlement of disputes, the proportionality test, relevance of interim measures of protection, and the powers and functions of multilateral instruments and bodies in the maintenance of international peace and security.

2.3. International liability for injurious consequences arising out of acts not prohibited by international law

12. The delegate of Japan, noted the Commission's decision to give precedence to issues of prevention over questions of remedial measures when considering this topic. While he recognized the importance of prevention, he believed that provisions relating to remedial measures should form the core of the topic. The delegate of India said that the Commission should exercise due care in delimiting the scope of the topic.

\subsection{Other matters}

13. The delegate of Syria, recalling that the topic 'Non-navigational uses of international watercourses' on the Commission's agenda had not been taken up for detailed consideration at its Forty-fourth Session, emphasized the concern he had expressed during the Islamabad session of AALCC regarding the Commission's draft articles on 'Obligation not to cause appreciable harm', 
'Obligation to cooperate' and 'Regular exchange of data and information', adopted on first reading.

14. Inviting the Commission to place greater emphasis on the progressive development of international law rather than the codification of customary international law, and to address newly emerging legal issues, the delegate of Japan recalled that AALCC had, at its Islamabad session, requested the Commission to take up as a priority item the topic 'Legal aspects of the protection of the environment of areas not subject to national jurisdiction (global commons)'.

\section{Decision}

15. In an essentially procedural decision adopted (Report, pp. 223-4) following discussion of the item (Report, pp. 104, 134-9), the Committee, inter alia, expressed appreciation for "the progress made on the question of the Establishment of an International Criminal Court".

\section{LEGAL PROBLEMS REFERRED TO THE COMMITTEE BY PARTICIPATING STATES}

\subsection{Status and treatment of refugees}

16. The Committee had before it the following documents prepared by the Secretariat: Status and treatment of refugees: $A A L C C$ 's model legislation on refugees: a preliminary study (Doc. No. AALCC/XXXII/KAMPALA/93/3); and Status and treatment of refugees: establishment of a 'safety zone' for the displaced person in the country of origin (Doc. No. AALCC/XXXII/ KAMPALA/93/4).

17. Document No. KAMPALA/93/3 notes inadequacies in the protective scope of international legal instruments such as the 1951 UN Convention relating to the Status of Refugees, and its 1967 Protocol. Citing progressive developments reflected in later regional arrangements such as the 1969 OAU Convention governing Specific Aspects of Refugee Problems in Africa and the 1984 Cartagena Declaration concerning refugee problems in Latin America, as well as in AALCC's 1966 Bangkok Principles, the Secretariat, in accordance with the mandate given to it at AALCC's Thirty-first Session, proposes the formulation of "model legislation" on refugees having the following structure, to be elaborated after further research if approved by the Committee: 
The draft structure of the Model Legislation

(1) Preamble;

(2) Decision should be made on the definition of 'refugee', should it be maintained as it is in the 1951 Convention and the 1967 Protocol or should it be enlarged in accordance with the foregoing discussion? It is proposed that the definition should at least reflect the enlarged definitions provided for in the 1969 OAU Convention, 1984 Cartagena Declaration and 1966 Bangkok principles which would facilitate states to adapt it to their particular requirements;

(3) Procedure for "refugee" status determination;

(4) Principle of family unity and dependency status;

(5) It is proposed to incorporate the following basic principles of refugee law:

(i) State Sovereignty;

(ii) Non-refoulement;

(iii) Non-discrimination;

(iv) Standards of treatment;

(6) Administrative measures;

(7) Rights of refugees;

(8) Duties of refugees;

(9) Assistance to refugees;

(10) Burden sharing;

(11) International monetary assistance to the country of origin while taking back its citizens;

(12) Punishment for violation of local laws;

(13) Association;

(14) Exclusion clauses;

(15) Miscellaneous clauses.

18. Document No. KAMPALA/93/4 contains the following proposals relating to the possible establishment of 'safety zones' for 'internally displaced people' or '... people who are uprooted from their homes [but] do not cross national borders to become recognized refugees', within their country of origin:

\section{THE STATUS OF SAFETY ZONE}

A Safety Zone which is established within the country of origin and with the consent of the country of origin, could be similar to a "neutralized zone" or a "demilitarized zone" as envisaged in Article 15 of the Geneva Convention (1949) and expanded by Article 60 of its Protocol I. The establishment of a Safety Zone during armed conflict could provide a parallel to the "Safety Zones" as envisaged by the Asian African Legal Consultative Committee. During the Twenty-eighth Session (Nairobi 1989) the AALCC presented 13 principles which provided a framework for the establishment of Safety Zone in the country of origin. For ready reference the principles are as follows:

“(i) The Safety Zone shall be established with the consent of the State of origin, through a resolution or recommendation of the United Nations;

(ii) The Safety Zone should be akin to a demilitarized zone or a neutral zone immune from hostile activities and a specified geographical area could be demarcated as such by a government notification; 
(iii) The Zone should be under international supervision, control and management to provide among others international protection to the persons residing therein;

(iv) The United Nations may designate and authorize an international organization or agency for administration and supervision of the Safety Zone;

(v) The State of origin and the neighbouring State which might receive the mass exodus could also be associated with the designated international organization or agencies in the supervision of the Safety Zone;

(vi) The designated international organization or agency shall be responsible for coordination and supervision of supply and distribution of food and other essential items and ensure facilties like drinking water, civic amenities and medical care. The cost of operations can be met through voluntary contributions by States, governmental and non-governmental humanitarian organizations;

(vii) The armed forces of the State of origin should withdraw from the Safety Zone and the status of the zone shall be respected by civilian as well as military machinery of the State of origin;

(viii) The authority in control of the Safety Zone shall provide international assistance/ protection to the individuals therin seeking asylum;

(ix) The United Nations may provide a multinational security force for the purpose of maintaining law and order within the Safety Zone.

(x) Persons seeking asylum in the Safety Zone shall be disarmed and will not be permitted to participate in any military activity or guerilla warfare against any State. Similarly asylum seekers shall not be a military target for any State;

(xi) The individuals residing in the Safety Zone shall be provided with the facility to seek and enjoy asylum in any other country;

(xii) If normalization is restored in the State of origin and the international organization or agency in charge of the Safety Zone is satisfied that the conditions are favourable and conducive to return, the persons residing in such zones shall be provided with all facilities to return to their permanent place of residence.

(xiii) The Safety Zone thus established shall be of temporary nature."

It is imperative in our view that such Safety Zones should be mandated by the Security Council whose decisions all the Member States have undertaken to accept and carry out in Article 25 of the Charter.

19. Introducing the topic, the Deputy Secretary-General emphasized the need for expansion of the scope of the term 'refugee' as defined in universal international legal instruments like the 1951 UN Convention to take account of contemporary developments, as well as for particular attention to be paid to categories of refugees specially vulnerable to the hardships arising from displacement, such as women and children. Referring to the difficulties faced by 'internally displaced persons' who were normally denied the status of 'refugees', he observed that the establishment of 'safety zones' could be among measures needed to alleviate their plight.

20. The Representative of the UN High Commissioner for Refugees (UNHCR) said that incorporation in national law of international standards for the treatment of refugees, as was contemplated in the proposal for 'model 
legislation' on the subject, was the most appropriate method, and sometimes the only method, of making those standards effective. Observing that no international organization had been entrusted with the responsibility of caring for 'internally displaced persons', and that no international legal instrument dealt comprehensively with their problems, he said that the position of UNHCR regarding the proposal for the establishment of 'safety zones' was reflected in its view that the following main principles should be kept in mind:

1. The Safety Zone proposal undoubtly has a place as a further contribution to increasing important endeavour to avert new flows of refugees by responding to the problems within countries of origin.

2. Caution should remain concerning the proposal which should not undermine the institution of asylum or conflict with basic principles of refugee protection.

3. Fundamental principles of human rights, refugee and humanitarian law, as well as principles guiding sovereign States need to be taken into account and indeed reconciled in any serious elaboration of the Safety Zone.

4. There would seem to be greater scope for Safety Zones in relation to persons fleeing conflict and generalized violence than to persons fleeing persecution where the State is either unwilling or unable to provide protection.

21. The Representative of the Organization of African Unity (OAU) said that Africa was host to over six million refugees, as well as over 12 million displaced persons either within or outside the countries of their nationalities. Having described the measures adopted under the aegis of OAU to alleviate their suffering, he called on States to address the root causes of the refugee problem, and to ratify both the OAU Convention governing Specific Aspects of Refugee Problems in Africa, and the African Charter on Human and Peoples Rights as soon as possible.

22. The delegates of China, Egypt, India, Iraq, Japan, Jordan, Republic of Korea, Kuwait, Nigeria, Tanzania and Thailand described measures adopted for resolving the problems of refugees within their respective territories. The delegate of Japan emphasized the political nature of the issues involved and their potential to affect the peace and security of the region. The delegate of Thailand was of the view that international law only imposed stringent obligations on receiving States, whereas the root causes of such problems lay in the refugees' countries of origin.

23. On the subject of 'safety zones', the delegate of Thailand expressed support for the 13 principles endorsed by AALCC at its Twenty-eighth Session. He said that the establishment of safety zones by the country of origin could lessen the burden borne by neighbouring States, observing that such zones should only be created with the consent of the country of origin. The delegate of Iraq said he did not support the idea of 'safety zones' as it 
amounted to the exercise of undue interference with the exercise of sovereignty by the country of origin. In his opinion, only the problems of 'refugees' properly so called, persons who had crossed an international border, should be considered, and the subject of safety zones should be removed from AALCC's agenda. The delegate of Palestine said that the rich countries saw in the establishment of safety zones the opportunity to interfere in the internal affairs of poor countries. Issues concerning the establishment of such zones were in his opinion, essentially political rather than legal.

24. The delegate of India inquired whether the phenomenon of 'internally displaced persons' was sufficiently widespread as to warrant study, and in any event, whether the role of law with respect to their creation was such as to justify its study by AALCC, which should concern itself with problems that were essentially legal. The delegate of Egypt, while acknowledging the humanitarian aspects of the safety zone concept, urged that the following unresolved legal aspects be taken into account in the course of any future study:

1. In the case of the absence of a Central Government, or a representative Central Government which could validly give State consent, how would such zones be established?

2. The criteria by which the Security Council should recommend the establishment of safety zones were unclear.

3. The concept of Safety Zones as an application of the International Humanitarian Law could be misused for not purely humanitarian reasons or at least be applied in a selective manner.

\section{Decision}

25. In the decision adopted (Report, pp. 225-6) following discussion of the item (Report, pp. 106-118), the Committee calls inter alia for (1) AALCC to continue with the study of model legislation on refugees, in close cooperation with UNHCR and the OAU, which would include study of legislation on refugees enacted by countries in Asia and Africa; and (2) further study of the concept of 'safety zones', as well as analysis of the role played by the United Nations in general, and UNHCR in particular in the recent past in that context.

\subsection{Law of international rivers}

26. The Committee had before it a document entitled Law of international rivers: a preliminary study relating to river system agreement (Doc. No. 
AALCC/XXXII/KAMPALA/93/6) prepared by the Secretariat, describing and analyzing institutional and legal aspects of agreements for the sharing of the waters of rivers in Asia and Africa. The Document dealt with three subject areas addressed by the International Law Commission in its consideration of the topic 'Non-navigational uses of international watercourses', (a) the scope of the term 'international watercourse'; (b) equitable and reasonable utilization and participation; and (c) protection and preservation of eco-systems.

27. Referred to the Committee in 1966 by Iraq (concerned with defining the term 'international river', and clarifying rules relating to the utilization of the waters of such rivers for purposes not connected with navigation) and by Pakistan (concerned with clarifying the rights of lower riparian States), this item serves (1) to focus discussion on areas of importance to member States that are not likely to be covered by the International Law Commission's work on the non-navigational uses of international rivers, as well as (2) to assist member States to monitor and formulate their views concerning progress of the work of the Commission.

\section{Decision}

28. During discussion of this subject on the basis of the Secretariat's study and the draft articles under consideration by the International Law Commission, the delegate of India observed that the diversity and complexity of the factors involved were such as to suggest that consideration of the item might be deferred, and placed on the Committee's agenda after the Commission had completed the second reading of its draft articles. After further discussion (Report, pp. 151-3) and a ruling by the President the Committee decided, inter alia, to request the Secretary-General to examine other crucial areas relating to river system agreements, and member States to transmit to him comments and information to enable him to do so; and to request "the International Law Commission to finish as early as possible the second reading of the draft Convention on Non-navigational Uses of International Watercourses and to take all necessary measures in order to conclude...a Framework Convention" on the subject (Report, page 231).

\subsection{Law of the sea}

29. The Committee had before it a document entitled Matters relatable to the work of the Preparatory Commission for the International Sea-bed Authority and for the International Tribunal for the Law of the Sea (Doc. No. AALCC/ XXXII/KAMPALA/93/7) prepared by the Secretariat, covering 
the work of the Preparatory Commission during its summer 1992 session, and containing comment on the question of the continued functioning of the Preparatory Commission, and the complementary relationship that should subsist between the role of the Preparatory Commission and that of the UN Secretary-General's informal consultations in promoting universality of the UN Convention on the Law of the Sea; on the need to bring the Convention into force, even through ratification or accession largely by the developing countries; the significance of the Convention in the context of the "UNCED process", since it constitutes a basis and a framework for successful implementation of the relevant parts of Agenda 21; and the scope of possible action with respect to Part XI of the Convention, that would take into account recent fundamental political and economic changes in international relations.

\section{Decision}

30. In the decision adopted (Report, pp. 227-8) following discussion (Report, pp. 151-3) of issues addressed in the Secretariat's document, the Committee inter alia:

2. Urges the Secretariat to continue its efforts to promote and ensure the entry into force of the Convention on the Law of the Sea as soon as possible particularly by member States of the AALCC, and to continue monitoring the work of the PREPCOM for the International Sea-bed Authority and for the International Tribunal of the Law of the Sea;

3. Urges the full and effective participation of the member States in the PREPCOM so as to ensure and safeguard the legitimate interests of the developing countries;

4. Reminds Member States to give timely consideration to the need for adopting a common policy and strategy for the period between the sixtieth ratification and the coming into force of the Convention in the early years of the Convention regime;

5. While appreciating the efforts for the universal acceptance of the Convention URGES the member States to safeguard the integrity of the Convention on the Law of the Sea;

3.4. Deportation of Palestinians in violation of international law, particularly the Fourth 1949 Geneva Convention, and the massive immigration and settlement of Jews in the Occupied Territories

31. The Committee had before it a document entitled The Legal Aspects of the Palestinian Question (Doc. No. AALCC/XXXII/KAMPALA/93/8) prepared by the Secretariat which contained inter alia a history of the problems dealt with, from their inception in the so-called Balfour Declaration of 2 November 1917, up to their consideration by organs of the United 
Nations, and General Assembly Resolution 45/68 adopted on 6 December 1990 calling for the convening of an International Peace Conference on the Middle East under the auspices of the United Nations; as well as discussion of the scope of protection afforded by the 1949 Geneva Convention relative to the Protection of Civilian Persons in Time of War; deportation of Palestinians from the Occupied Territories, and their rights as 'protected persons' to return there, and to receive compensation. Annexed to the document was a Report of a Seminar organized jointly by AALCC and the League of Arab States (New Delhi, November 1992) and a 'Resolution of Solidarity' adopted by the Seminar.

32. The Assistant Secretary-General, introducing the Secretariat documents, observed that the recent deportation of $\mathbf{4 1 5}$ Palestinians to the 'no-man's land' between Israel and Lebanon, Israel's refusal to abide by Security Council Resolution 799, and the failure of two Special Envoys of the Secretary-General of the United Nations to persuade Israel to allow all 415 persons deported to return, had brought into sharp focus the issues for discussion under this item.

\section{Decision}

33. In the decision adopted (Report, pp. 232-6) following discussion of the item (Report, pp. 157-161), the Committee inter alia:

1. Expresses its concern at the continuing denial and deprivation of the inalienable human rights of the Palestinian people including inter alia the right of selfdetermination, the right to return and the establishment of an independent State on their national soil;

4. Supports the just cause of the Palestinian people and their struggle for selfdetermination;

5. Supports the UN Security Council Resolution No. 799 of December 1992 and calls upon the Security Council member States to implement unreservedly its own resolution by using, if necessary, economic and diplomatic sanctions and calls the five Permanent Members of the Security Council to regard all the resolutions equally and not selectively, respected and enforced;

6. Agrees to hold an inter-sessional meeting, if still needed, on the deported Palestinians and to put this question on the agenda of the next AALCC meeting;

7. Condemns the Israel's policy in the occupied territories and the deportation of Palestinian people and demands that the 415 Palestinians recently expelled to Lebanon be immediately allowed to return home in conformity with the decision of the Security Council in Resolution 799;

8. Strongly Condems Israel's policy of immigration and settlement of Jews in Palestinian and other Arab occupied territories and Southern Lebanon and Syrian Golan Heights in flagrant violation and contravention of human rights; 
9. Strongly Deplores the recent decision taken by the Israeli Supreme Court which gave the political authority the right to violate International Law and the Fourth Geneva Convention of 1949 by legalizing the deportation of over 400 Palestinians;

10. Demands that Israel respects the principles of International Law and all International Conventions which have a bearing on the matter;

11. Condemns also Israel's policy of appropriation and illegal exploitation of the natural resources of occupied territories in contravention of the principles of permanent sovereignty over natural resources;

12. Requests the Secretary-General of the Committee to continue to monitor the events and developments in the occupied territories of Palestine;

\subsection{Responsibility and accountability of former colonial powers}

34. The Committee had before it a document entitled Responsibility and accountability of former colonial powers (Doc. No. AALCC/XXXII/KAMPALA/93/9) prepared by the Secretariat, recalling the background to the item, and describing existing legal arrangements relating to the return or restitution of cultural property to the countries of origin. Introducing the document, the Secretary-General invited the Committee's attention to the International Convention on the Means of Prohibiting and Preventing the Illicit Import, Export and Transfer of Ownership of Cultural Property, adopted under the aegis of UNESCO in Paris on 14 November 1970, noting that some 26 member States of AALCC were already Parties to the Convention. He also referred to recent initiatives to strengthen implementation of the Convention through preparation of a model bilateral treaty for prevention of crimes against cultural heritage, and preparation (in cooperation with the International Institute for the Unification of Private Law (UNIDROIT)) of a draft convention on stolen or illegally exported cultural objects. The Secretary-General also noted that the OAU had an item on its agenda that closely resembled the item under discussion, and proposed that, if the Committee approved, he should work on the item in consultation with OAU.

35. During the discussion, the delegate of the Libyan Arab Jamahiriya referred to the decision by the Committee on this item at its Thirty-first Session and observed that many aspects of it were of concern to the developing countries. He recalled that the President of Uganda had himself, in the course of his inaugural address, emphasized the importance of this item, and had, in addition, noted that many people from Asia and Africa had been transported to other countries for use as slaves or to carry out forced labour. He was aware that Nigeria had requested the colonial powers to pay compensation for the enslavement of its people. The delegate of Japan recalling his delegation's 
interventions at previous sessions of the Committee, expressed reservations regarding the item, indicating that it was, in his view, of a highly political nature and not appropriate to be dealt with in a multilateral forum like the Committee.

\section{Decision}

36. In the decision adopted (Report, p. 236) following discussion of the item (Report, p. 154-6), the Committee inter alia:

1. Requests the Secretary-General to hold consultations with the Organization of African Unity on the preparation of a joint study on issues concerning Responsibility and Liability of Former Colonial Powers.

2. Calls upon the Member Countries to provide relevant instructions to the Secretariat relating to their claims in regard to the restitution of their cultural property:

3. Requests the Secretariat to prepare an analytical study on the ongoing work in this field as well as the need for wider participation in the 1970 UNESCO Convention;

\section{MATTERS OF COMMON CONCERN HAVING LEGAL IMPLICATIONS}

4.1. The UN Conference on Environment and Development: outcome and followup (including Framework Convention on Climate Change and Convention on Biological Diversity

37. The Committee had before it a document entitled United Nations Conference on Environment and Development: Rio de Janeiro, 3-14 June 1992 (Doc. No. AALCC/XXXII/KAMPALA/93/10) prepared by the Secretariat, containing studies of four documents adopted at UNCED: the Rio Declaration on Environment and Development (Earth Charter); Agenda 21; the UN Framework Convention on Climate Change; and the Convention on Biological Diversity. The Secretariat examines each document from the perspective of the membership of AALCC as reflected in the "Statement of General Principles of International Environmental Law" endorsed by the Committee at its Thirtyfirst Session held at Islamabad. Each study contains introductory paragraphs, a review of the main provisions of the document concerned, and general observations. Excerpts from the introductory paragraphs and general observations in each study are reproduced below. [Note: The paragraphs of each study are numbered individually—Ed.] 


\section{RIO DECLARATION ON ENVIRONMENT AND DEVELOPMENT (EARTH CHARTER)}

‥

22. The Rio Declaration consists of a preamble and 27 principles (see Annex 3). The preamble indicates that the Declaration is built upon the 1972 Stockholm Declaration on Human Environment, and that its goal is to establish a new and equitable global partnership through the creation of new levels of cooperation among States, key sectors of societies and people. The 27 operational principles deal respectively with a wide range of various substantial elements:...

\section{GENERAL OBSERVATIONS}

...

34. Some countries, non-governmental organizations and people might not be fully satisfied with the description of certain principles contained in the Declaration, since the Declaration failed to make strong commitment concerning the provision of new, additional and adequate financial resources and transfer of environmentally sound technologies on preferential and concessional basis to developing countries, or because some principles that they were reluctant to accept were incorporated in the Declaration. Nevertheless, if the Declaration is considered as a whole and in a comprehensive and realistic perspective, the conclusion is that, taking into account that the Declaration was a compromise reached after prolonged, fierce debates and hard negotiations among States and State groups, particularly between the developing South and the developed North, the current text of the Declaration is the best reflection of the consensus among the States that could be reached at the present level of human understanding. It must be acknowledged that it constitutes a delicate balance among the different interest groups ...

35. As far as the form and formulation of the Rio Declaration is concerned, it is significant to note certain characteristics that the Declaration has:

(a) The use of the Rio Declaration on Environment and Development as the title of the instrument on elaborating principles of general rights and obligations of States in the field of environment and development aptly reflects the need for the integration of and the linkage between environment and development, as indicated by the General Assembly Resolution 44/228. It is also the title that the AALCC has proposed.

(b) The Rio Declaration is in its nature not legally binding as a multilateral Convention, but given the fact that it was adopted by over 100 world leaders at the Summit level, it would have very strong moral authority of international community.

(c) The text of the Declaration is quite concise and can be easily understood by the average person. Its language is to a great extent appealing and inspiring and that is conducive to enhancing wide public awareness of environmental and developmental concerns, and to promoting public participation in the environmental protection.

(d) The Declaration has not only reaffirmed but also developed the ideas and principles contained in 1972 Stockholm Declaration on Human Environment. It thus represents the deepening and enhancement of human cognition on human kind itself, the nature, and the relationship between them which hopefully will lead to the 21st Century on a new and more enlightened basis.

36. In the context of the involvement of the AALCC, the Member States of the Committee might be satisfied with that most of the basic ideas and principles advocated and upheld by the Committee at the Islamabad Session in February 1992 are to a large 
extent appropriately reflected and incorporated in the Rio Declaration, including inter alia the following:

- the protection and preservance of the global environment is the common concern of mankind which should be pursued in full cooperation and global partnership;

- the environment and development are intrinsically and inextricably linked. The need to protect the environment requires to be viewed in a perspective where due emphasis is accorded to promoting economic growth and social development of developing countries, including the eradication of poverty and ignorance, meeting basic needs and enhancing the quality of life;

- the principle of sustainable development should be given due effect, and development shall not be pursued in such a manner as would endanger the environment;

- the responsibility of member States of the international community shall be common but differentiated and the application and enforcement of environmental standards by the developing countries shall be in accordance with their respective capabilities and responsibilities;

- the principle of precaution shall also be given due effect. All members of the international community shall ensure that no appreciable or significant harm is caused to the environment and the environment does not suffer severe and irreversible degradation;

- the need to protect intergeneration equities within the context of the progressive development and codification of international environmental law; and

- the instrument to be adopted by the UNCED should include appropriate provision for the peaceful settlement of environmental disputes.

37. However, as mentioned before, some member States particularly developing countries might be disappointed in the wording of principles regarding the financial resources and technology transfer. Most member States of the Committee are of the view that the developed countries, international and regional organizations and financial institutions should consider, explore and make provision for new, additional and adequate financial resources to the developing countries to meet the objectives of sustainable development and the protection and preservation of the environment. The developed countries should also, in the interest of the common future of mankind, seriously consider making available to the developing countries environmentally sound technologies on a preferential and non-commercial basis. Those points of view are also shared by the Group of 77. During the final Session of the Prepcom for UNCED held in New York in March 1992, the G-77 renewed its proposal to include into the Rio Declaration the principle which would have provided that in view of their main historical and current responsibility for global environmental degradation and their capability to address this common concern, the developed countries shall provide adequate, new and additional financial resources and environmentally sound technologies on preferential and concessional terms to developing countries to enable them to achieve sustainable development. This proposal was, however, deemed as unacceptable and thus was rejected by some industrialized countries, particularly by the United States.

Through intense negotiations, a final compromise was reached to the effect that in view of the different contributions to global environmental degradation, States have common but differentiated responsibilities. The developed countries acknowledge the responsibilities that they bear in the international pursuit of sustainable development in 
view of the pressures their societies place on the global environment and of the technology and financial resources they command, and thus agree that States should cooperate to strengthen endogenous capacity-building for sustainable development by improving scientific understanding through exchange of scientific and technological knowledge and by enhancing the development, adaptation, diffusion and transfer of technology including new and innovative technology. It seems that the commitment by the developed countries in this respect is quite weak, and the demands of developing countries have not been fully met.

38. On the other hand, however, some more inspiring and favourable terms have been included in the relevant chapters of Agenda 21. It provides in Chapter 33 dealing with financial resources and mechanism that in light of the global benefits to be realized by the implementation of Agenda 21 as a whole, the provision to developing countries of effective means, inter alia, financial resources and technology, without which it will be difficult for them to implement fully their commitments, will serve the common interest of developed and developing countries and of humankind in general, including future generations (para 33.3). It is further stated that the implementation of the huge sustainable development programmes of Agenda 21 will require the provision to developing countries of substantial new and additional financial resources (para 33.10). It is further agreed that the provision of new and additional financial resources should be both adequate and predictable (para 33.12). These to some extent go to meet the concern of the developing countries on the important issue of funding mechanism which was a result of very intense negotiations within the Working Group during the Rio Conference under the very able Chairmanship of Ambassador Koh.

39. With regard to environmentally sound technologies, Chapter 34 of Agenda 21 refers to the need for favourable access to and transfer of such technologies, in particular to developing countries (para 34.4). It also refers to help to ensure the access, in particular of developing countries to scientific and technological information, promote, facilitate and finance, as appropriate, the access to and the transfer of environmentally sound technologies and corresponding know-how, in particular to developing countries on favourable terms, including on concessional and preferential terms, as mutually agreed, taking into account the need to protect intellectual property rights as well as the special needs of developing countries for the implementation of Agenda 21 (para 34.14). This delicate balance was also arrived at after prolonged negotiations within the Working Group.

40. It might also be somewhat regretable that the proposal by the AALCC on the protection of the marine environment has not received appropriate reflection in the Rio Declaration despite every effort made by the Secretariat of the Committee. During the whole period of the preparation for UNCED, the AALCC had, on quite a few occasions, appealed to the Prepcom that the protection of the marine environment should be accorded great importance in drafting the Rio Declaration. Emphasis had also been made concerning the critical need for the universal ratification of the 1982 UN Convention on the Law of the Sea...At the Fourth Session of the Prepcom for UNCED, the delegation of the AALCC further proposed, in cooperation with the Prepcom for the International Seabed Authority, to include a new paragraph in the Rio Declaration, which would read as follows:

"All States and people shall protect and preserve the marine environment. They shall facilitate international communication, and shall promote the peaceful use of the 
seas and oceans, the equitable and efficient utilization of their resources, the conservation of their living resources, and the study of the marine environment. For doing so, a universal adherence to the United Nations Convention on the Law of the Sea, which contains a comprehensive global framework and lays down fundamental rules for all relevant ocean-related activities, would solidify those already widely accepted principles."

Unfortunately, they were deemed as unacceptable by some countries, and therefore were not inserted in the Rio Declaration. Nevertherless, the AALCC will resolutely continue its endeavours to promote universal adherence to the 1982 UN Convention on the Law of the Sea.

\section{AGENDA 21}

...

42. The principal outcome of the Rio Conference was the adoption of Agenda 21, which addresses the pressing problems of today and also aims at preparing the world for the challenge of the next century. It is thus a century blueprint to save our fragile planet earth. Being a comprehensive and dynamic programme, running to over 800 pages, Agenda 21 consists of a preamble, four sections, and 40 chapters. It covers a wide range of programme areas, including social and economic dimensions, conservation and management of resources for development, strenghening of the role of major implementing groups and the means of implementation.

43. Among the issues addressed by Agenda 21, are the issues related to legal instruments, institutional arrangements and financial resources as well as transfer of environmentally sound technologies. These issues have also been the main areas of concern and consideration by the AALCC. The discussion below will focus on the legal instrument and institutional arrangements. The financial resources and technology transfer will be discussed separately in connection to the Framework Convention on Climate Change.

44. The progressive development and codification of international law in the field of the environmental protection and sustainable development is designated as one of the main means of the implementation of Agenda 21, and is the subject of Chapter 39, entitled 'International Legal Instruments and Mechanisms'. The programme areas that constitute Chapter 39 are described in terms of the basis for action, objectives and activities.

\section{$\cdots$}

\section{COMMENTS AND OBSERVATIONS}

53. While going through the text of Chapter 39, it might be concluded that the basis for action, objectives and activities regarding international legal instruments and mechanisms in the context of the implementation of Agenda 21 are quite well identified and considered. Inter alia, issues concerning the importance and means of further development of international law on sustainable development, of the integration of environmental and developmental concerns, and adequate and effective participation of developing countries in the negotiation, implementation, review and governance of international legal instruments are appropriately addressed. It is thus a valuable guidance to the future work in this regard.

54. The overall objective of the review and development of international environ- 
mental law, as indicated by Chapter 39 , includes two aspects. The first is to evaluate and promote the efficiency of that law. The second is to promote the integration of environment and development policies through effective international agreements or instruments. These two aspects are intrinsically linked, and cannot be pursued in isolation from each other. An effective instrument of environmental law must be one that successfully integrates the environment and development. Therefore, the review of existing international legal instruments and future law-making on environment should, in principle, be closely linked with the need to embody the principle contained in the Rio Declaration and to implement effectively Agenda 21, taking into account the special needs of developing countries.

55. When evaluating the past performance and effectiveness of existing international agreements or instruments concerned, some basic criteria should be used: whether or not and to what extent does an agreement or instrument under the evaluation:

(a) meet the need to integrate the environment and development and is conducive to the promotion of sustainable development;

(b) take into account the special needs and concerns of developing countries;

(c) have adequate incentives to encourage the participation of developing countries; and

(d) implemented and complied by the contracting parties, and the existence of appropriate mechanisms for the enforcement of the agreement and for the settlement of disputes over the implementation.

56. As regards the future law-making process, benefiting from the past experiences, it is important to avoid the proliferation of new agreements or instruments without making concrete arrangements for their realistic implementation. It is equally important that the effective participation of all countries concerned and in particular developing countries, in negotiation and governance should be ensured and necessary and appropriate technical and financial assistance should be provided for this purpose.

57. While the adoption of some new convention may indeed be necessary, such as the one envisaged on nuclear safety in the framework of the International Atomic Energy Agency, more efforts should be made to bring into force a large number of existing international multilateral or regional treaties that have not yet become effective through identification and addressing difficulties which prevent some States, in particular developing countries, from participating in those treaties, and where appropriate reviewing and revising them with a view to promotion of their wider participation and more effective implementation.

58. The role of the International Law Commission in the progressive development and codification of international environmental law should be underscored and further strengthened. The AALCC has made a proposal requesting the International Law Commission to include an item related to the protection of environment in its long-term work programme and take it up as a priority item. This may include an elaboration of legal norms on general rights and obligations of States in the field of the environmental protection and sustainable development, including development of law regarding liability and compensation for the victims of environmental damages. It is understood that the International Law Commission is sympathetic to this request.

59. With regard to the settlement of environmental disputes, the AALCC member States believe that the principle of peaceful settlement of international disputes including environmental disputes, is a matter of great significance in the international 
community today. Besides political settlement through negotiation and consultation, the judicial settlement of legal disputes, particularly recourse to the International Court of Justice, is becoming all the more important. The members of the International Community should take advantage of the growing confidence in the International Court of Justice, and make efforts to facilitate the judicial settlement of environmental disputes through the ICJ. In this regard, the initiative undertaken by the SecretaryGeneral of the United Nations in establishing a Trust Fund to assist States in recourse to the ICJ for dispute settlement should be appreciated and supported.

60. Finally, the Secretariat of the Committee wishes to express its willingness to render legal assistance, as appropriate, and on request to the member States of the Committee in the field of national legislation regarding the environmental protection and sustainable development.

\section{INTERNATIONAL INSTITUTIONAL ARRANGEMENTS}

61. The important issues regarding international institutional arrangements in the follow-up to the Rio Conference are addressed in Chapter 38 of Agenda 21 in terms of the basis for action, objectives and the envisaged institutional structure.

62. In light of the provisions of Chapter 38, the institutional arrangements shall be guided by the following principles:

(a) the intergovernmental follow-up to the UNCED process shall be within the framework of the UN system, with the General Assembly being the Supreme Policymaking forum that would provide overall guidance to governments, UN System and relevant treaty bodies. At the same time, governments, as well as regional economic and technical cooperation organizations, have a responsibility to play an important role. Their commitments and actions should be adequately supported by the UN system and multilateral financial institutions:

(b) there is a need for institutional arrangements within the UN system in conformity with, and providing input into the restructuring and revitalization of the UN in the economic social and related fields, and the overall reform of the UN. Implementation of Agenda 21 and other conclusions of the Rio Conference shall be based on action and result oriented approach and consistent with the principles of universality, democracy, transparency, cost-effectiveness and accountability;

(c) The UN system is uniquely positioned to assist governments to establish more effective patterns of economic and social development with a view to achieving the objectives of Agenda 21 and sustainable development;

(d) All agencies of UN system have a key role to play in the implementation of Agenda 21 within their respective competence. To ensure proper coordination and avoid duplication, there should be an effective division of labour, and all bodies of the UN should be required to elaborate and publish reports of their activities on the implementation of Agenda 21 on a regular basis. Serious and continuous review of their policies, programme, budgets and activities will also be required;

(e) The continued active and effective participation of non-governmental organizations, the scientific community and private sectors as well as local groups and communities are important in the implementation of Agenda 21; and

(f) The institutional structure will be based on agreement on financial resources and mechanisms, technology transfer, the Rio Declaration and agenda 21.

63. The overall objective of the institutional arrangements is the integration of environmental and developmental issues at national, subregional, regional and 
international levels.

64. The specific objectives are as follows:

(a) To ensure and review the implementation of Agenda 21 so as to achieve sustainable development in all countries;

(b) To enhance the role and functioning of the UN system in the field of environment and development;

(c) To strengthen cooperation and coordination on environment and development in the UN System;

(d) To encourage interaction and cooperation between the UN system and other intergovernmental and non-governmental subregional, regional and global institutions and non-governmental organizations in the field of environment and development;

(e) To strengthen institutional capabilities and arrangements required for the effective implementation, follow-up and review of Agenda 21;

(f) To assist in the strengthening and coordination of national, subregional and regional capacities and actions in the areas of environment and development.

(g) To establish effective cooperation and exchange of information between the UN organs, organizations, programmes and the multilateral financial bodies, within the institutional arrangements for the follow-up of Agenda 21;

(h) To respond to continuing and emerging issues relating to environment and development;

(i) To ensure that any new institutional arrangements would support revitalization, clear division of responsibilities and the avoidance of duplication in the UN system and depend to the maximum extent possible upon existing resources.

65. Guided by the above-mentioned principles and objectives, the overall institutional structure as envisaged, the main elements of which consist of the following:

(a) The General Assembly: The General Assembly is designated to be the principal policy-making and the appraisal organ on matters relating to the follow-up to the Rio Conference. The General Assembly would organize a regular review of the implementation of Agenda 21. It could consider the timing, format and organizational aspects of such a review, and consider holding a special Session no later than 1997 for the purpose of overall review and appraisal of Agenda 21, with adequate preparation at a high level.

(b) The Economic and Social Council: The ECOSOC would assist the General Assembly through overseeing system-wide coordination, overview on the implementation of Agenda 21 and making recommendations in this regard. The ECOSOC would also undertake the task of directing system-wide coordination and integration of environmental and developmental aspects in the UN policies and programmes and make appropriate recommendation to the General Assembly, specialized agencies concerned and Member States. Appropriate steps should be taken to obtain regular reports from specialized agencies on their plans and programmes related to the implementation of Agenda 21, pursuant to Article 64 of the Charter of the United Nations. The ECOSOC should organize a periodic review of the work of the proposed Commission on Sustainable Development, as well as of system-wide activities to integrate environment and development, making full use of its high-level and coordination segments. 
(c) Commission on Sustainable Development: A high-level Commission on Sustainable Development should be established to serve as the intergovernmental mechanism, in accordance with Article 68 of the Charter of the United Nations. The Commission should consist of representatives of states elected as members, with due regard to equitable geographical distribution. Its main functions should include the monitoring of progress in the implementation of Agenda 21; to consider information provided by Governments; to review the progress in the implementation of the commitments contained in Agenda 21; to receive and analyze relevant input from competent non-governmental organizations, in the context of the overall implementation of Agenda 21; to enhance the dialogue; and to provide appropriate recommendations to the General Assembly through the ECOSOC. The Commission would report to the ECOSOC. The first meeting of the Commission should be convened no later than 1993. The General Assembly, at its 47th Session, should determine specific organizational modalities for the work of the Commission.

(d) The Secretary-General: Strong and effective leadership on the part of the Secretary-General is considered vital.

(e) Inter-agency coordination mechanism: There is a need for a high-level inter-agency coordination mechanism under the direct leadership of the Secretary-General. The task is proposed to be given to the Administrative Committee on Coordination (ACC) headed by the Secretary-General, ACC would thus provide a vital link and interface between the multilateral financial institutions and other UN bodies at the highest administrative level. All heads of agencies and institutions of UN should be expected to cooperate fully with the SecretaryGeneral.

(f) Advisory Body: It is suggested to establish a high-level advisory board consisting of eminent persons knowledgeable about environment and development, appointed by the Secretary-General in their personal capacity.

(g) Secretariat support structure: It should provide support to the work of both intergovernmental and inter-agency coordination mechanisms. Concrete organizational decisions fall within the competence of the Secretary-General.

(h) Organs, programmes and organizations of the UN system: All relevant bodies of the UN system, such as UNEP, UNDP, UNCTAD, and specialized agencies, will have an important role within their respective areas of expertise and mandate in supporting and supplementing national efforts.

(i) Regional and subregional cooperation and implementation: The regional Commissions, regional development banks and regional economic and technical cooperation organizations can make contributions in this regard. Particularly, the regional Commissions as appropriate, should play a leading role in coordinating regional and subregional activities by sectoral and other UN bodies and shall assist countries in achieving sustainable development.

(j) National Implementation: States may wish to consider setting up a national coordinational structure responsible for the follow-up on Agenda 21.

(k) Cooperation between UN bodies and international financial organizations: The Secretary-General and Heads of UN Programmes, organizations and multilateral financial organizations have a special responsibility in forging effective cooperation between UN bodies and multilateral financial organizations, not 
only through the UN high-level coordination mechanism, but also at regional and national level.

(1) Non-governmental organizations: Relevant non-governmental organizations, the private sectors, various groups etc., should be given opportunities to make their contributions and establish appropriate relationship with the UN system.

66. In assessing the institutional arrangements envisaged above, the member States of the Committee would be pleased to hear that many of their propositions and proposals on the institutional follow-up to the Rio Conference are appropriately reflected in the provisions of Chapter 38 of Agenda 21. Inter alia those on the importance of the most efficient and effective use of the existing financial and human resources and nonproliferation of new institutions; on the supremacy of the General Assembly and the role of the ECOSOC in the institutional structure, on the establishment of a more comprehensive inter-governmental Committee based on restructuring several existing Committees of ECOSOC, and set up of a special expert advisory group, as well as the strengthening of the UNEP have been endorsed.

67. It has been the view of the AALCC that the institutional follow-up to the Rio Conference should ensure the improvement and strengthening of the existing institutional mechanism within the United Nations system with the General Assembly as the Supreme policy-making forum in the context of the integration of environment and development and the effective implementation of Agenda 21. A new institutional arrangement should ensure the full and effective participation of all countries, in particular developing countries in the policy-making process, make full use of existing institutions of the UN system, and promote better cooperation and coordination among States, UN bodies, specialised agencies and other organizations involved in the field of environment and development.

68. Therefore, the Member States of the Committee may wish to consider using the above-mentioned elements as some of the criteria for the evaluation of the feasibility and effectiveness of the institutional structure proposed by Chapter 38 of Agenda 21 . 69. As regards the General Assembly, it is important that its principal function in the political deliberation and policy guidance related to environment and development should be further enhanced and reinforced. In this context it may be suggested that one main committee of the General Assembly be designated as responsible. In addition the General Assembly may decide to convene meetings at the ministerial level for the purpose of overall review and appraisal of Agenda 21.

70. With respect to the ECOSOC, while the restructuring and revitalization of the United Nations in the economic, social and related fields is underway, the institutional need for the integration of environment and development and for the effective implementation of Agenda 21 should be fully taken into account and be given priority. The vital role of the ECOSOC in this regard should be greatly strengthened and enhanced. 71. ECOSOC should welcome the agreement on the establishment of the Commission on Sustainable Development as the main inter-governmental mechanism. The AALCC has proposed that the Commission could be constituted through combining and restructuring a number of existing Committees of ECOSOC dealing closely with related matters. About the composition of the Commission, it is necessary to underscore further the importance of wider involvement and participation of developing countries and the preservation of the democratic principle in the decision-making process of the Commission. 
72. To establish an effective and efficient inter-agency coordination mechanism in the field of the environmental protection and sustainable development is undoubtedly crucial in the implementation of Agenda 21 and achieving the objective of sustainable development. The efforts should be made to have all the relevant organizations or institutions. Particularly the multilateral financial institutions involved in the coordination mechanism and to ensure the best cooperation in a team spirit.

\section{UN FRAMEWORK CONVENTION ON CLIMATE CHANGE}

1. By its Resolution 45/212 of 21 December 1990, the General Assembly established the Inter-governmental Negotiating Committee for a Framework Convention on Climate Change (INC) and mandated it to prepare an effective framework Convention on climate change containing appropriate commitments, and any related instruments as might be agreed upon. At the subsequent session, the General Assembly reviewed the progress thus made in the INC and urged it "to expedite and successfully complete the negotiations as soon as possible and to adopt the Framework Convention on Climate Change in time for it to be opened for signature during the United Nations Conference on Environment and Development."

2. The Inter-governmental Committee for a Framework Convention on Climate Change held five sessions, the last one in two parts. The second part of the fifth session was held in New York from 28 April to 9 May 1992. At the beginning of that Session, the Chairman of the INC introduced a set of working papers which were prepared after consultations with the INC Bureau and a number of delegations. These working papers were the focus of hectic deliberations for the whole week. On 9 May 1992 the INC adopted the final text of the "United Nations Framework Convention on Climate Change" and recommended that it be opened for signature at the United Nations Conference on Environment and Development scheduled to be held at Rio de Janeiro from 3-14 June 1992. It also adopted a resolution which inter alia provided for certain follow-up measures during the interim period between the signing of the Convention and its entry into force.

...

4. The Framework Convention consists of a Preamble, 26 Articles and two Annexes. Articles 1 to 3 contain general provisions such as definition, objective and principles. Article 4 is the key article dealing with the commitments. Articles 5 and 6 further elaborate commitments specifically in respect of research and systematic observation, education, training and public awareness. Articles 7 to 11 deal with the institutional arrangements, including the financial mechanism. Article 12 is another article dealing with commitments concerning communication of information related to implementation of the Convention. Articles 13 and 14 provide for amicable settlement of any disagreement or dispute. Articles 15 to 20 and 22 to 26 stipulate provisions concerning final clauses such as amendments, adoptation of protocols, signature, entry into force, reservation, withdrawal etc. Article 21 entitled interim arrangements, deals with the arrangements prior to the coming into force of the Convention. Annex I contains the list of countries which includes 25 members of the OECD and 11 countries that are undergoing the process of transition to market economy. Annex II contains the list of OECD members. 


\section{GENERAL OBSERVATIONS}

$\cdots$

2. Although the final text represents only a 'package deal' and the Convention as a whole fell short of expectations of several delegations on many counts, nevertheless it is a significant first step. It provides a basis on which other measures have to be built.

3. Global warming poses an environmental threat of unprecedented nature. However, the uncertainties in predictions with regard to the timing and magnitude due to lack of adequate understanding of the phenomenon and other material evidence have to be taken into account. The IPCC has made a tremendous contribution in establishing the scientific basis of the Convention. It is hoped that the six tasks agreed on at the Fifth Session of the IPCC (Geneva, March 1991) would be useful in adopting further measures to implement the provisions of the Convention.

4. Thanks to the generous financial assistance provided by the INC, representatives of a large number of developing countries were able to participate at the INC Sessions. This helped them immensely to increase their awareness and get first hand information about the problems of climate change and the measures to tackle them.

5. It is heartening to note that as many as 155 States including the EEC have signed the Convention at Rio during the UNCED in June 1992. Some of the States which have not yet signed the Convention have however expressed concern and dissatisfaction over certain provisions in the Convention. Some States have expressed serious reservations regarding the provisions on specific commitments. The fossil-fuel producing countries are concerned that in the implementation of the Convention they might have to pay a higher price than others, due to repercussions inherent in the implementation process. Although the provisions dealing with special situations take into consideration this aspect, however, it is not quite satisfactory to them. Much more has to be done to allay their concern and to bring them in the Convention's fold. The first and foremost thing, therefore, is to win their confidence and make the Convention universally acceptable. It is not the intention to suggest that the Convention should be amended at the very first instance. The present text is flexible enough to accomodate the genuine concerns of many non-signatories.

6. In the present text of the Convention the provisions concerning financial mechanism and transfer of technology to the developing countries need to be strengthened. The developing countries have lost the battle to secure any firm commitments from the developed countries in respect of these two matters. The vague assurance and feable attempts would not sooth their feelings.

7. It is a matter of satisfaction that the resolution on interim arrangements adopted by the INC along with the text of the framework convention considered it essential to involve in future negotiations all participants in the INC irrespective of whether they are signatories to the Convention or not. This would avoid any discrimination and leave the doors open for constructive negotiations in the crucial phase of future of negotiations. It is expected that the General Assembly at its Forty-seventh Session will endorse the Report of the INC fifth Session and recommend the convening of INC Sixth Session probably in early December this year to initiate necessary arrangements to be made for the preparation of the first Session of the Conference of the parties as specified in the Convention.

8. The Convention would come into force on the nineteenth day after the date of deposit of the fiftieth instrument of ratification, acceptance, approval or accession. 
Further as provided in Article 7 the first session of the Conference of Parties would be held not later than one year after the date of entry into force of the Convention. The first session of the Conference of Parties would have an exhaustive agenda for consideration. A tentative list of items as deduced from various provisions of the Convention might include:

(i) Adoption of the rules of procedure of the Conference of Parties as well as those of the subsidiary bodies established by the Convention. These procedures will include decision making procedures for matters not covered in the Convention (Article 7.3).

(ii) Designation of a Permanent Secretariat and necessary arrangements for its functioning. (Article 8.3).

(iii) A review of the adequacy of the specific commitments undertaken by the developed country parties.

(iv) Review of the information communicated by the developed countries parties on their policies and measures related to mitigation of climate change (Article 4.2(b).

(v) Approval of methodologies for calculations of emissions by sources and removals by sinks of greenhouse gases (Article 4.2(c)).

9. The success of the first session of the Conference of the Parties would very much depend on the preparatory work undertaken during the interim period until the Convention comes into force. It is good that the INC and the IPCC are actively involved in this process. It would ensure continuity and avoid the hassles involved in establishing a new set-up.

10. The General Assembly at its Forty-Seventh Session will consider the necessary arrangements required for continuation of the functioning of the INC, including the financial aspects. It would be desirable if the expenses during the interim period could be met by the resources generated by the implementation mechanism of the Convention itself. The United Nations is already facing serious financial crisis. Such a move would lessen the burden on the United Nations.

...

\section{CONVENTION ON BIOLOGICAL DIVERSITY}

6. ... [T]he UNEP Governing Council by its decisions $15 / 34$ and SS.II.5 appointed an Ad Hoc Working Group of Legal and Technical Experts with a mandate to negotiate an international legal instrument for the conservation of biological diversity. At its first session held in Nairobi from 19-23 November 1990, the Group focused on the elements for possible inclusion in a global framework Convention on Biological Diversity. On the basis of its consideration of these elements the session requested the UNEP Secretariat to prepare a draft Convention on Biological Diversity which was presented to the second session of the Ad Hoc Working Group held in Nairobi from 25 February to 6 March 1991 (UNEP/Bio.Div./WG.2/2/2). The second session discussed parts of the draft Convention and identified a number of issues for further clarification with the help of notes to be prepared by the UNEP Secretariat. It made recommendations to the Secretariat on the revision of the draft Convention. The Session also requested the Executive Director to convene a meeting of a regionally balanced group of lawyers (Lawyers' Meeting) to review the draft Convention as revised by the Secretariat. The session also made important decisions on procedural and organizational matters...

7. The UNEP Governing Council, at its sixteenth session, by Decision 16/42 renamed 
the Ad Hoc Working Group of Legal and Technical Experts on Biological Diversity as the Intergovernmental Negotiating Committee (INC) for a Convention on Biological Diversity clarifying that the change of name did not mean a new negotiating body nor affect the continuity of the process of elaborating the Convention. The INC was split into two working groups. Working Group I was assigned almost two-thirds of the Draft Convention. Working Group II was allotted specific draft articles which constituted the heart of the Draft Convention. The successful elaboration of the Convention depended upon agreement being reached on the issues which were being tackled by Working Group II. Those included access to genetic resources; access to and transfer of technology including biotechnology; and financial resources and funding mechanisms. 8. The first session of the INC was held in Madrid from 24 June to 3 July 1991; the second session in Nairobi from 23 September to 2 October 1991; the third session in Geneva from 25 November to 4 December 1991; the fourth session in Nairobi from 6 to 15 February 1992, and the fifth and final session in Nairobi from 11 to 19 May 1992 at which the text of the Convention on Biological Diversity was eventually finalized. Subsequently ... at the United Nations Conference on Environment and Development (UNCED) held in Rio (Brazil) it was opened for signature from 5 to 14 June 1992. The Convention is now open for signature at United Nations headquarters in New York until 4 June 1993.

9. As of 29 June 1992, the Convention had received 157 signatures. From among the member States of the AALCC, 35 States have signed the Convention. These are as follows:

Arab Republic of Egypt; Bangladesh; China; Cyprus; Gambia; Ghana; India; Indonesia; Iran; Japan; Jordan; Kenya; DPR Korea; Republic of Korea; Kuwait; Malaysia; Mauritius; Mongolia; Nepal; Nigeria; Oman; Pakistan; Philippines; Qatar; Senegal; Sri Lanka; State of Palestine; Sudan; Tanzania; Thailand; Turkey; Uganda; United Arab Emirates; Yemen; and Botswana.

The non-signatory AALCC member States are Iraq; Libya; Saudi Arabia; Sierra Leone; Singapore; Somalia; and Syrian Arab Republic.

10. Significantly, the USA, the largest economy in the world, did not sign the Convention. Lack of patent protection is stated to be the main reason for which the USA refused to sign the Convention. The US delegation also claimed that the Convention would take away American jobs, though how this would happen was never explained. ...

\section{GENERAL OBSERVATIONS}

45. Although the Convention on Biological Diversity seems to have received worldwide affirmation as is evident from the fact that it has been signed by 157 countries, its success and effectiveness will depend on the actual implementation of the crucial provisions of the Convention such as those related to access to genetic resources (Article 15), access to and transfer of technology (Article 16) and financial resources and a funding mechanism (Articles 20 and 21).

46. There is an intrinsic interlinkage between access to genetic resources, transfer of technology and financial assistance to the developing countries to enable them to carry out their obligations under the Convention. The value of genetic resources depends on the technology to use them. Although genetic resources, for the most part, are concentrated in the developing countries, the technologies to exploit them are mainly with the industrialized countries which are protected by intellectual property rights. In view of the obstacles posed by the intellectual property regimes to the diffusion of 
technology, which in the context of this Convention, would mainly be biotechnology, a suspicion lurking in the minds of the developing countries has been that the developed countries wanted them to conserve their genetic resources without giving them any corresponding financial or other compensation. It is for this reason that the developing countries insisted during the negotiations on a trade-off with the developed countries in the INC negotiations that in return for providing access to this resource, they are able to secure access to relevant technologies. This would enable them to build their own capability to maintain in situ collections, including the use of technologies such as cryogenics (freezing techniques) and biotechnology. Biotechnology is a fast-growing research-intensive industry born of scientific advances in genetic engineering dating from 1973. These advances have made it possible to create in a laboratory new organisms that can be used to make commercial products ranging from improved medicines, to better strains of crops, and to bacteria for use in pest control. Biotechnology has immense potential for contributing to improved health care, food production, environmental problems and industry in developing countries.

47. It was in response to these concerns of the developing countries that the texts of Articles 15 and 16 were revised to reflect those concerns. Thus, Article 15 invests the national governments with the authority to determine access to their genetic resources and to provide access only on mutually agreed terms and with their prior informed consent, unless waived by them. It also requires the Contracting Parties to carry out scientific research based on the genetic resources provided by the other contracting parties with their full participation and, where feasible, in their own countries. It also requires the Contracting Parties to share in a fair and equitable way the results of such scientific research and the benefits accruing from the commercial exploitation of genetic resources with the Contracting Parties providing those resources. This sharing has to be on mutually agreed terms.

48. What causes some concern, however, are some of the provisions in Article 16 on transfer of technology. Those provisions, inter alia, provide that in the case of technology protected by patents and other intellectual property rights, the transfer of technology is to be effected in conformity with those rights. This has been modified somewhat in the case of the Contracting Parties providing the genetic materials by the provision that such transfers will be effected on mutually agreed terms notwithstanding the protection of intellectual property rights. This would necessarily imply that even in the case of Contracting Parties supplying the genetic materials, only those technologies would be transferred over which the Governments would be having ownership rights or control, but this would not be possible in case of those technologies which are in the hands of private owners and are protected by intellectual property rights. ${ }^{4}$

49. According to the Global Biodiversity Report prepared by the World Resources Institute and other world conservation organizations, finding patentable products is not a quick process. A rule of thumb in screening samples is that only one out of 10,000 actually leads to a marketable product. The right to own and license genetic materials developed from discoveries is imperative since without the guarantee of exclusive use, nobody would commit the amount of money-on an average about US $\$ 100$ millionrequired to bring each biotechnologically created drug in the market.

4 It may be pointed out that the US biotechnology industry has grown from 1 firm in 1976 to more than 1,100 today with revenues reaching US $\$ 5,800$ million (Economic News from USA, June 1992). 
50. Against this, it can be contended that the experience of the developing countries, which have been the main repository of the genetic materials, has been that most of them have been unfairly denied compensation for genetic substances found within their territory. A frequently cited example is Vincristine, a cancer drug with a multi-million dollar market developed from the rosy periwinkle of Madagascar which received none of its profits. It is, therefore, justly argued by these countries that without some right to the profits from products developed from their genetic resources they will have few incentives to continue protecting biologically diverse areas.

51. Since the biotechnology industry continually needs samples of genetic materials found in biologically diverse developing countries, which provide the basis for genetically engineered products, it has been suggested that the biotechnology firms in the industrialized countries would find it advantageous to join with biodiverse countries for a regular source of new genetic samples. In this context, the World Resources Institute has recommended the two-year agreement between Costa Rica's National Biodiversity Institute (INBio) and the US pharmaceutical giant Merck and Company as the model for similar agreements with other developing countries. INBio was established in 1989 to catalogue and manage Costa Rica's remarkable biodiversity. Under the Agreement, Merck is paying US \$1 million during the next two years for the opportunity to examine the plants and other species that INBio is collecting: INBio prepares from the samples chemical abstracts that are sent to Merck's laboratories. INBio is reported to receive an unspecified amount of royalities ( 1 to 3 per cent) from the sales of any products developed from the genetic materials of these samples. Merck is also donating equipment to INBio and training the Institute's scientists.

52. Even if INBio receives only 2 per cent of royalties from the pharmaceuticals developed from Costa Rica's biodiversity, it would take only 20 drugs for INBio to be able to earn more funds than Costa Rica currently gets from coffee and banana, its two major exports. The INBio-Merck Agreement is the only one of its kind in the developing world, and because of its success it is likely to be followed in other developing countries. Mexico has already set up its own Commission on biodiversity and both India and Kenya are examining the possibilities. (US Information Service, New Delhi. Economic News from USA August 1992). Thus, for a share of reasonable profits and access to technologies, it would be in the interest of developing countries to seek such agreements with the biotechnology firms in the industrialized countries.

53. Although in the Biodiversity Convention, developing countries have somewhat succeeded in limiting the impact of intellectual property rights on the transfer of technology including biotechnology, they should equally be cautious and concerned about the developments taking place in the ongoing Uruguay Round negotiations under the GATT auspices related to Trade Related Intellectual Property Rights (TRIPS). GATT is, strictly speaking, not the forum for discussing the question of intellectual property for which there are separate fora such as WIPO. The reason why the US was nevertheless interested in bringing intellectual property into GATT is because by linking it with trade, it gives the US the possibility of retaliatory action which would not have been possible in other fora.

54. Patenting, the most familiar form of IPR, until very recently only applied to inventions which were applicable in industry. Earlier even in western countries, society had prevented this kind of monopolization of knowledge being extended to important areas such as treatment of diseases and agriculture. But over the years, the idea of 
intellectual property is being extended to plants also. A special type of property right adapted to plants was created which is known as plant breeders' rights (PBRs). With the takeover of the seed companies by the multinational corporations and the coming of biotechnology, there is now a demand for a stronger monopoly of plant Breeder Rights. Under these rights the farmers will be prevented from using the variety to develop new varieties for 20 years for which the right might be granted. Since patents give the possibility of making unlimited number of claims, it gives the multinationals the opportunity to claim not only individual varieties but also characteristics and even species and genera. Already patents have been given for plants in the US and Europe: in 1985 in the US and 1989 in Europe. The home countries of these multinationals have taken a stand supporting Plant Breeders Rights in various fora. In the TRIPs negotiations as well as in the WIPO, the US has been arguing for the stronger form of monopolies represented by PBRs to be made applicable to plants and animals. ${ }^{5}$ Developing countries should take a concerted stand against these development lest agricultural development is allowed to take place in a particular direction which will be principally in the interest of multinational corporations.

55. Another issue of vital importance relates to the question of financial resources and the financing mechanism for the application of the convention nationally and internationally. The basic principles of each Contracting State providing financial support for its national activities related to conservation and sustainable use of biodiversity, and the commitment of the developed country Parties to provide new and additional resources for meeting the agreed incremental costs to the developing country Parties in fulfilling their obligations under the Convention, have been enshrined in the Convention. However, the incremental costs and a list of developed countries and their scale of contributions have as yet to be established by the Conference of the Parties.

56. Similarly, the financial facility which will administer the funds to the developing countries has still to be agreed on by the Conference of the Parties. Pending the finalization of these arrangements, the Global Environment Facility (GEF) of the UNDP, UNEP and the World Bank has been instituted as the financial facility for the interim period. The GEF was established in 1990 with a funding of US $\$ 1300$ million to provide grants on highly concessional terms to developing countries to meet the costs of well appraised conservation projects in four sectors: global warming, biological diversity, pollution of international waters and depletion of the protective ozone layer. Subsequently, at the insistence of the developing countries, land degradation problems, primarily in desertification and deforestation, that are tied to one of four other problem areas, were made eligible for funding.

57. At present, the industrialized countries that have made contributions to the GEF control approval of projects. The UNDP and the UNEP supply the technical and scientific expertise to evaluate projects and the World Bank manages them when approved. The Convention, however, insists that before the GEF becomes the funding mechanism for the interim period it would be necessary to make it more transparent and

5 Usha Menoh, 'Intellectual Property Rights and Agriculture Development', Economic and Political Weekly, New Delhi 6-13 July 1991; UPOV. Diplomatic Conference for the Revision of the International Convention for the Protection of New Varieties of Plants, Geneva, 4 to 19 March 1991. (Article 14)-this question has not been dealth with in the Convention but left to be decided upon by the Conference of the Parties. 
democratic in its functioning. Recently, 15 developing countries including China, India and Brazil negotiated with the United States, West European nations and Japan at a two-day meeting in Washington in May $1992 .{ }^{6}$ It has been agreed to expand the membership and to share power in the GEF. Revised procedures are being prepared, under which decisions will be taken by consensus and if a vote is called for, developing countries as a group or industrialized countries as a block can veto a project.

\section{SUGGESTED POINTS FOR CONSIDERATION OF THE LEGAL ADVISERS OF AALCC MEMBER STATES}

In the light of the foregoing, the AALCC Secretariat would like to suggest the following points for consideration of the Legal Advisers:

(1) National legislation to implement the Convention and its provisions. Apart from enacting the Convention in the national domain, the Convention requires the Contracting Parties to enact national legislation regulating certain specific matters such as those related to (a) integration of conservation and sustainable use of biodiversity in national policies (Article 6); identification and monitoring of components of biological diversity important for conservation and sustainable use (Article 7); protection of threatened species and populations (Article 8); incentives for the conservation and sustainble use of biodiversity (Article 11); promoting understanding and awareness about the importance of conservation of biological diversity (Article 13); regulation of access to genetic resources (Article 15); sharing the results of research and development and benefits arising from the commercial exploitation of genetic resources (Article 15); access to and transfer of technologies including biotechnology for Contracting States providing genetic resources (Article 16); encouraging development and use of technologies including indigenous and traditional technologies (Article 18) and participation of developing countries in biotechnological research and ensuring safety in the handling of biotechnology (Article 19). A major issue in this connection will be whether one comprehensive legislation covering all these aspects or separate legislation devoted to specific matters would be appropriate and necessary.

(2) The question of liability and compensation for causing damage to the biodiversity or environment of other States.

(3) The inter-related issues of access to genetic resources and transfer of technology including biotechnology which are covered by intellectual property rights (Articles 15 and 16).

(4) Financial resources for developing countries and the financing facility (Articles 20 and 21): the establishment of the financing facility contemplated by Article 21, an indicative list of incremental costs to developing countries, and their eligibility for access to the funds; a list of developed contracting Parties who would contribute to the proposed facility and their scale of contributions have all been left to the Conference of the Parties to work out.

(5) Interim Financing Facility (Article 39): Article 39 institutes the existing Global Environment Facility (GEF) as the interim financing facility until the Conference of the Parties decides on this question finally. Before it commences its formal functioning

6 US Information Service, New Delhi. Economic News from USA (June 1992). 
for the Convention, it is required to be democratized and made transparent in its operations. What aspects should be incorporated in this process?

38. Introducing the Secretariat document, the Secretary-General emphasized the importance of the four main documents analyzed and commented on therein. In his opinion, integration of environment and development would be the guiding principle for future environmental activities. He noted that the General Assembly had already taken action that would revitalize and enhance the role of the organization in that field, referring, in particular, to the establishment of a high level Commission on Sustainable Development in order to ensure effective follow-up of Agenda 21; to the establishment of an inter-governmental committee for the elaboration of an international convention to combat desertification in those countries experiencing serious drought, particularly in Africa expected to complete its work by June 1994; and to the convening of a global conference on the sustainable development of small island developing States in April 1994.

39. The Secretary-General noted the concerns of some member States of AALCC, especially the oil-producing States, regarding implementation of the Framework Convention on Climate Change, and urged their participation in the follow-up process with a view to correcting any imbalance that might have arisen due to approaches taken by the developed countries which were themselves responsible for the largest emissions of carbon dioxide and other greenhouse gases. In his view the developing countries had a vital stake in the successful implementation of the provisions dealing with access to and transfer of technology, and funding mechanisms, in the Convention on Biological Diversity. He declared that the work programme of the AALCC Secretariat would include monitoring and reporting on ratification and implementation of both Conventions, as well as assisting member States in their consideration of the question of liability and compensation for damage caused to the biodiversity or environment of a State; transfer of technology, including biotechnology, covered by intellectual property rights; financial resources for developing countries; improvement of the democratization and governance of the Global Environment Facility; national implementing legislation, and the work of the Commission on Sustainable Development. Noting that the General Assembly had, at its Forty-seventh Session decided to establish an Inter-governmental Negotiating Committee to draw up an international convention to combat desertification, he observed that the Secretariat's early involvement would provide it with the opportunity to assist member Governments as it had done in regard to other global environmental agreements. 
40. The delegate of Japan emphasized the importance of early effective implementation of the Framework Convention on Climate Change (FCCC) and the Convention on Biological Diversity (CBD). He declared his Government's commitment to strengthen overseas technical and financial cooperation with respect to afforestation and the sustainable management of forests, and its support for the efforts of the developing countries in environmental matters, outlining the objectives set by Japan in connection with disbursement of some 7 to 8 billion US dollars in official development assistance in the field of the environment over a 5-year period from fiscal 1992. He informed the meeting of the establishment of International Environmental Technology Centres of UNEP at Osaka and Shiga which would, inter alia, promote the transfer of environmentally sound technologies to developing countries, their special focus being the sustainable development of big cities, and the preservation of fresh water resources.

41. Referring to issues connected with financing measures outlined in Agenda 21 and mechanisms for facilitating global technology transfer, the delegate of the Republic of Korea urged that the international community focus its efforts on the creation of an effective Commission on Sustainable Development which would monitor UNCED follow-up action. He described his country's environmental protection programme, as well as environmental cooperation in the Northeast Asian Region, which comprised the Korean Peninsula, Japan, Russia, China and Mongolia.

42. The delegate of the Islamic Republic of Iran emphasized the need for the developing countries to fulfil the right to development (General Assembly Resolution 41/128, 4 December 1986, and Rio Declaration, Principle 3) and the dilemma confronting those who must decide between measures to prevent environmental degradation and measures to promote sustained economic growth and development, when the values and priorities involved in each case were in conflict-with each other. He observed that the key to resolving many environmental problems, including those of desertification and land degradation was the provision of additional financial resources and the transfer of the necessary technologies.

43. The delegate of Jordan observed that the mere adoption of Agenda 21 could not be expected to resolve the world's environmental problems, which included the problems of Somalia, lack of water and food in some of the developing countries, the priorities of some international organizations which spent money on academic research rather than on useful enterprises, and the non-participation of industrialized countries in important international convention regimes. Emphasizing the need for each country to develop its own national environmental strategy, he proposed that each member State (a) establish a committee for that purpose, (b) carry out studies on the state of its 
environment, and (c) establish training programmes for training of the necessary personnel.

44. The delegate of China suggested that the new 'global partnership' (Rio Declaration, Principle 7) would be characterized by the following five features: enhanced international cooperation; respect for the basic norms (five principles) of international law; an equitable and just order; proper handling of issues relating to financial resources and technology transfer; and active and effective participation of the whole international community. The results of UNCED, he believed, would depend upon the credibility and effectiveness of the measures taken by way of follow-up.

45. The delegates of Indonesia, DPR Korea, Kuwait, Uganda, Pakistan, Sri Lanka, Tanzania, Libyan Arab Jamahiriya, India and Nepal made statements in which they recognized the importance of the Rio Declaration, Agenda 21 and the two Conventions adopted at UNCED, noted the problems that would confront the developing countries in their efforts to implement their provisions (essentially inadequacy of financial resources and lack of the necessary technologies), and called for enhanced international cooperation with a view to resolving them.

\section{Decision}

46. In the decision adopted (Report, pp. 229-30) following discussion of the item (Report, pp. 119-134), the Committee inter alia:

1. Directs the Secretariat to continue monitoring the follow-up work in the aforesaid fields and prepare studies aimed at promoting ratifications of the United Nations Framework Convention on Climate Change and the Convention on Biological Diversity and the institutional arrangements resulting from the decisions of the General Assembly at its Forty-seventh session;

2. Requests the Secretary-General to initiate preparation of studies on the proposed international convention to combat desertification;

3. Welcomes the conclusion of a Memorandum of Understanding on cooperation between the Asian-African Legal Consultative Committee and the United Nations Environment Programme;

4. Approves the proposal to convene an Expert Group Meeting on Environmental Law jointly with the UNEP;

5. Invites the Organization of African Unity and the League of Arab States to participate and initiate joint programmes on environmental issues in cooperation with the Asian-African Legal Consultative Committee;

6. Urges the member Governments to make voluntary contributions to the AALCC's Special Fund on Environment; ... 


\subsection{UN Decade of International Law}

47. The Committee had before it a document entitled The United Nations Decade of International Law: Report of the Secretary-General (Doc. No. AALCC/XXXII/KAMPALA/93/2) containing an outline of the history of the item and its consideration by AALCC, to which are annexed a Report submitted by the Secretary-General of AALCC to the Secretary-General of the United Nations in response to General Assembly Resolution 46/53 of 9 January 1992; and the statement of the Secretary-General of AALCC at the Symposium on 'Teaching, Study, Dissemination and Wider Appreciation of International Law in the Developing Countries', held in Beijing, 24-6 August 1992.

48. The delegate of China referred to two seminars on international law convened at Beijing in 1991 and 1992 respectively, as contributions to the programme of activities for the Decade. He said his Government shared with the majority of the members of the international community, the desire to strengthen the role of the International Court of Justice. The delegate of the Islamic Republic of Iran, declaring that it was imperative that all member States of AALCC uphold the primacy of the rule of law in inter-State relations, said that international organizations, both universal and regional, should also promote the acceptance of, and respect for, principles of international law. In that connection he recalled his Government's proposal made in the General Assembly's Sixth Committee for the holding of a week-long Congress on Public International Law.

49. The delegate of Japan, emphasizing the significance of the Decade, urged all member States to strengthen the role of the International Court of Justice, and to accept the compulsory jurisdiction of the Court with a view to facilitating recognition of the rule of law within the society of States. He announced that his Government proposed to contribute US $\$ 25,000$ to the UN Secretary-General's Trust Fund for Peaceful Settlement of International Disputes by recourse to the Court.

50. The delegates of the Arab Republic of Egypt, India and Libya re-affirmed their support for the objectives of the Decade, placing special emphasis on the peaceful settlement of international disputes. The delegate of Egypt said that one means of realizing the objectives of the Decade was to ensure support for the idea of formulating a Convention on peaceful settlement of disputes. The delegate of Tanzania, recalling that most developing countries had not been able to participate at the two earlier Peace Conferences, should avail 
themselves of the opportunity to influence the world order by making a tangible contribution to the development of international law at the proposed third Peace Conference. The Decade should be a period characterized by action rather than rhetoric, when States ratified existing conventions and enacted domestic legislation to give effect to them.

51. The delegate of Kenya supported the objectives of the Decade, observing that the developing countries were often victims of opportunistic interpretation and application of international law. The delegate of Iraq objected to what he termed the 'double standard' applied by the Security Council in deciding whether a State had or had not violated the terms of the Fourth 1949 Geneva Convention and Protocol I thereto. He observed that jurists were obliged to stop the use of force regardless of who the actors were.

52. The delegate of Cyprus said that the proposed draft Code of Crimes against the Peace and Security of Mankind should clearly define crimes such as aggression, 'ethnic cleansing', demographic alteration and illegal transfer of populations, suggesting that the proposed International Criminal Court should be vested with compulsory jurisdiction. This would reflect the will of the community to apply international law even-handedly and in a uniform matter.

\section{Decision}

53. In the decision adopted (Report, p. 237-8) following discussion of the item (Report, p. 99-105), the Committee inter alia:

1. Reaffirms the importance of strict adherence to the principles of International Law as enshrined in the Charter of the United Nations;

2. Reiterates that many of the political, economic and social problems which riddle the Member States of the International Society can be resolved on the basis of the law;

3. Welcomes the various initiatives taken by member States of the Committee in the implementation and observance of the Decade;

4. Requests member States to continue to give serious attention to the observance and implementation of the Decade;

5. Requests the Secretary-General to apprise the Secretary-General of the United Nations of the initiatives taken by the Committee in this regard;

6. Decides that the item be given serious attention and steps be taken to place the same on the agenda of the Meeting of the Legal Advisers of Member States of the Committee to be convened at the UN Office in New York during the Forty-eighth Session of the General Assembly;

7. Accepts the offer of the Government of Qatar to host an International Seminar under the auspices of the AALCC on the implementation of the principles of the new international law within the new international order; 


\subsection{Debt burden of developing countries}

54. The Committee had before it a document entitled Debt burden of developing countries: guidelines for re-scheduling (Doc. No. AALCC/XXXII/ KAMPALA/93/5) prepared by the Secretariat, which described the evolution, nature and extent of the external indebtedness of Asian and African countries and, having discussed various initiatives taken in international fora for dealing with the 'debt crisis', focuses on 'debt rescheduling' or modification, with the concurrence of a creditor, of the payment arrangement of an existing debt, so as to afford the debtor a measure of temporary relief. In conclusion, the document offers guidelines for re-scheduling, or an outline of the various steps to be taken by a State when rescheduling or renegotiating its debts, keeping in view, in particular, the interests of developing countries. The Committee had not, at its two immediately preceding meetings (Cairo, 1990; Islamabad, 1992) been able to discuss this item for lack of time.

55. The delegate of Indonesia said that any measures for alleviating the debt burden of a developing country should not only enable it to pay its debt, but also to sustain economic growth and re-vitalize the development process. He emphasized the importance of exchanges of views among the developing countries and the sharing among them of their experience in debt management. The delegate of Uganda, agreed that the debt re-scheduling process dealt with in the Secretariat document would offer a developing country only temporary relief, unless the underlying causes of the problem, such as stagnation of exports and increased import burdens, were fully addressed. He said that rescheduling methods should take into account the development and investment needs of each country.

\section{Decision}

56. As discussion of the item (Report, p. 150-2) could not be continued for lack of time, the Committee's decision (Report, page 239), inter alia, urges member States to initiate necessary dialogue with other members of the international community, including various international agencies to find a durable and workable solution to the debt problem,' and directs the Secretariat to continue to update its study.

\subsection{Preparation for the World Conference on Human Rights}

57. The Committee had before it two docume-ts prepared by the Secretariat: Preparation for the World Conference on Humin Rights (Doc. No. AALCC/ XXXII/KAMPALA/93/11), and Draft Working Paper submitted by the Secretariat concerning General Principles on Human Rights (Doc. No. 
AALCC/XXXII/KAMPALA/93/11A). Other reference documents provided by delegations included: the Joint Statement of the Attorneys-General and Ministers of Justice of Eastern, Central and Southern African States on the Administration of Justice and Human Rights, issued in Nairobi in October, 1992; and the Report of the Asia-Pacific Workshop on Human Rights Issues.

58. At the commencement of its Thirty-second Session, the Committee established a Working Group consisting of the delegates of the Arab Republic of Egypt, Bangladesh, China, India, Indonesia, Iran, Japan, Kenya, Syria, Thailand and Uganda, as well as the observers from Swaziland and Zimbabwe, and requested it to prepare a draft Kampala Declaration on Human Rights for consideration by the Committee. Mr. LUCIAN TiBARUHA (Uganda) served as chairman of the Working Group.

59. Introducing the Report of the Working Group, the Assistant SecretaryGeneral said that the draft Kampala Declaration on Human Rights annexed to the Report had been adopted unanimously by the Working Group, which had taken note of the position of the delegate of Japan, who had reservations on some of its paragraphs, but did not wish to block the adoption of the Declaration.

\section{Decision}

60. Following discussion of the Report of the Working Group (Report, pp. 180-7) and the incorporation of some amendments proposed by member States (Report, pp. 166-71), the Committee decided inter alia to adopt the Kampala Declaration on General Principles of Human Rights (Report, pp. 188-194, also reproduced in UNdoc. A/CONF.157/PC/62/Ad.), and to request the Secretary-General to submit the Declaration to the Fourth Session of the Preparatory Committee for the World Conference on Human Rights scheduled to be held in Geneva in April 1993; and to approve the AALCC's Work Programme on the item which included preparation by the Secretariat of a general assessment of the main outcome of the World Conference on Human Rights, and of additional studies on the development of international law in the field of human rights, including refugee and humanitarian law (Report, pp. 241-2). The Kampala Declaration on Human Rights adopted by the Committee reads as follows (pre-ambular paragraphs omitted): 'THE ASIAN-AFRICAN LEGAL CONSULTATIVE COMMITTEE

$$
\ldots
$$

\section{DECLARES THAT}

1. The Universal Declaration of Human Rights proclaims a common understanding of all the peoples of the world in the field of human rights and gives help, guidance and inspiration to humanity in the promotion of human rights and fundamental freedoms. 2. Since the adoption of the Universal Declaration of Human Rights, the United Nations has through the adoption of various international instruments made much 
progress in defining standards for the promotion, enjoyment and protection of human rights and fundamental freedoms. It is an obligation of the members of the international community to ensure the observance of these rights and freedoms.

3. The International Covenant on Civil and Political Rights, the International Covenant on Economic, Social and Cultural Rights, the Declaration on the Granting of Independence to colonial countries and peoples, the International Convention on the Elimination of All Forms of Racial Discrimination, Declaration on the Right to Development as well as other conventions, declarations, proclamations, decisions, principles and resolutions in the field of human rights adopted under the auspices of the United Nations, the specialized agencies and regional intergovernmental organizations, have created new standards and obligations to which all countries should conform.

4. All States that have not yet ratified or acceded to the International Covenant on Civil and Political Rights, the International Covenant on Economic, Social and Cultural Rights and other international human rights conventions should make very effort to do so.

5. It is the obligation of all members of the international community to ensure that the principles enshrined in the Charter of the United Nations and in other international human rights instruments are enforced. All Governments, organizations and peoples should promote the universal respect and observance of human rights.

6. Peace and security are not only Human Rights in themselves but are also a necessary prerequisite for the full realization of all other inalienable and indivisible human rights. Efforts should be made to save present and future generations from the scourge of wars and armed conflicts, and to maintain international peace and security in accordance with the Charter of the United Nations.

7. The validity and universality of human rights, whether civil, political, economic, social or cultural is indispensable and these rights must be protected, upheld and promoted by all. To this end, all governments have a special duty to ensure that the constitutions and laws of their States that relate to human rights are in compliance with international human rights standards and are observed and respected.

8. The right to development is an inalienable human right. The vital importance of economic and social development to the full enjoyment of human rights, should be further recognized and underscored. It is undoubted that the existence of widespread poverty is a main reason resulting in the insufficient enjoyment of human rights by the majority of humanity. Therefore, all States should cooperate in the essential task of eradicating poverty as an indispensable requirement for universal realization of human rights.

9. Sustainable Development and the Environment are intrinsically linked and should not be considered in isolation from each other. Sustainable Development cannot be merely an abstract concept and should be promoted and strengthened through the process of social and economic development. The human right to a clean and salubrious environment requires to be progressively developed and codified.

10. The principle of the indivisibility and interdependence of human rights has been recognized and must be given effect in policy formulation and implementation. Civil and political rights cannot be disassociated from economic, social and cultural rights in their conception as well as universality and the satisfaction of economic, social and cultural rights are a guarantee for the enjoyment of civil and political rights. None of these rights should be given precedence over the others. 
11. The primary responsibility for implementing and giving effect to human rights is at the national level. Consequently, the most effective system or method of promoting and protecting these rights has to take into account the nation's history, culture, traditions, norms and values. There is no single universally valid prescription model or system. Whilst the international community should be concerned about the observance of these rights, it should not seek to impose or influence the adoption of their criteria and systems on developing countries. It should be sensitive to the unique aspects of each situation and establish impartiality and genuine concern on human rights problems by objective and acceptable factual analysis of events and situations.

12. The promotion and protection of the rights of vulnerable groups such as women, children, refugees, disabled, migrant workers and minorities should be given special attention and priority.

13. The international community should devise effective action plans and concrete measures to overcome the current obstacles to the full realization of human rights, namely, threat to peace and security, foreign aggression and occupation, colonization, racism, racial discrimination, apartheid, terrorism, xenophobia, ethnic and religious intolerance and human rights abuse thereof, denial of justice, torture, unfair and unjust international economic order, widespread poverty and illiteracy, worsening economic situation of developing countries and heavy burden of external debts.

14. The rule of law and the administration of justice in every country shall be inspired by the principles enshrined in the Universal Declaration of Human Rights and other international human rights instruments relating to the administration of justice.

15. The international community recognizes the importance of the rule of law, the independence of the judiciary and the administration of justice in the development process. To this end, governments, regional and international financial institutions and the donor community are called upon to give necessary financial resources and assistance to enable those entrusted with the administration of justice to carry out their tasks.

16. The international community affirms that training, equipment and incentives be provided to those State agencies involved in the administration of justice within the developing countries on the basis of their need and request. To this end, governments, regional and international financial institutions and the donor community are urged to give the necessary resources.

17. The international community calls upon States to ensure that law enforcement Officials shall in the performance of their duties respect and protect human dignity and maintain and uphold human rights of all persons in accordance with international standards enshrined in the Universal Declaration of Human Rights and international human rights instruments regarding arrest, prosecution, detention, imprisonment, protection against torture, cruel, inhuman or degrading treatment or punishment.

18. Cooperation between national, regional and international organizations in the field of human rights should be encouraged by all peoples of the world.

19. Non-governmental organizations in the field of human rights have an important role in the promotion of human rights. Their ideals and activities could be mobilized into the process of universal realization of human rights.

20. The public awareness and concerns of human rights should be enhanced. Citizens should have appropriate access to information concerning their rights, and opportunity to participate in decision-making process. States should encourage and facilitate the public awareness and participation. 
21. The United Nations system in the field of human rights is urged to use existing mechanisms and resources effectively and efficiently. The improvement of existing institutional mechanisms and the enhancement of their better cooperation and coordination should be undertaken. All the members of the international community are called upon to contribute additional financial and other resources for human rights activities.'

\subsection{Trade Law Matters}

61. The Committee had before it the following documents prepared by the Secretariat: Progress Report covering the legislative activities of the United Nations and other international organizations concerned with International Trade Law (Doc. No. AALCC/XXXII/KAMPALA/93/12) covering the work of the UN Commission on International Trade Law (UNCITRAL) at its Twentyfifth Session (4-22 May 1992); the work programme approved by the Governing Council of the International Institute for the Unification of Private Law (UNIDROIT) at its 71st Session (22-24 June 1992); the current legislative programme of the UN Conference on Trade and Development (UNCTAD); the current programme and activities of the UN Industrial Development Organization (UNIDO); and subjects currently under study by the Hague Conference on Private International Law. Legal issues involved in the matter of privatization of State-owned enterprises (Doc. No. AALCC/ XXXII/KAMPALA/93/13) containing a revised preliminary study, which adds materials supplied by Kuwait and Turkey; and Progress Report on AALCC's Centres for Arbitration (Doc. No. AALCC/XXXII/KAMPALA/93/14) which covers the work of arbitration centres established at Kuala Lumpur (1978), Cairo (1979) and Nigeria (1989), and foresees the establishment of additional centres, including one at Tehran.

62. The Sub-Committee on International Trade Law Matters, which convened under the chairmanship of Mr. MIRZA Asaduzzaman ALFAROUQUI (Bangladesh) to consider these documents and report thereon to the Committee, was able to discuss only the 'Progress Report covering the legislative activities of the United Nations, etc.' in view of the delegations' preoccupation with important institutional issues and the consequent limitation of time available for the work of the Sub-Committee. The Report of the Sub-Committee is on pages 173-9 of the Report.

\section{Decisions}

63. The Committee, after consideration of the Report of the Sub-Committee on International Trade Law Matters, decided unanimously to adopt it (Report, page 171). 
After discussion of the relevant documents (Report, p. 97-9), the Committee adopted a decision commending progress made in the activities of AALCC's regional arbitration centres (Report, p. 195-215, 218) and resolutions recommending that member States consider ratifying or acceding to the UN Convention on the Carriage of Goods by Sea, 1978 (Hamburg Rules) (Report, page 219); and that member States give due consideration to the UNCITRAL Model Law on International Commercial Arbitration (Report, page 220).

64. Following discussion (Report, p. 150-1) of the study entitled Legal issues involved in the matter of privatization of State-owned enterprises, the Committee adopted a decision which inter alia urges all member States and Observer Delegations to make available to the Secretariat information relating to their privatization plans or programmes (Report, page 240 ).

65. A decision of the Committee (Report, page 243) notes the establishment on 1 February 1992, following an initiative of the Republic of Korea, of AALCC's Data Collection Unit, and inter alia, urges all member States to furnish to it information and materials in the official language of AALCC, "including copies of bilateral or multilateral agreements concluded, ratified or acceded to by them in the fields of international trade and economic relations, as well as legislation enacting such agreements in the national domain." 